\title{
ENVIRONMENTAL STRATEGY AS SOCIAL PRACTICE IN A FOREST-BASED ENTERPRISE: A DESCRIPTIVE STUDY
}

\author{
Beatriz Christo Gobbi ${ }^{1}$, Mozar José de Brito², Valéria da Glória Pereira Brito ${ }^{3}$
}

(received: August 7, 2009; accepted: May 28, 2010)

\begin{abstract}
This article aims to study the environmental strategies of a forest-based, cellulose pulp-producing organization by employing strategic theory as social practice and interpretative, descriptive research methods. The analyses of the results show that the studied organization has sought to develop environmental strategies characterized by eco-efficient practices, the mitigation of harmful socio-environmental impacts and the creation of a responsible socio-environmental work ethic.
\end{abstract}

Key words: Participation, organization, cellulose.

\section{ESTRATÉGIA AMBIENTAL COMO PRÁTICA SOCIAL EM UMA EMPRESA DE BASE FLORESTAL: UM ESTUDO DESCRITIVO}

\begin{abstract}
RESUMO: Este artigo teve por objetivo estudar as estratégias ambientais de uma organização de base florestal e produtora de celulose. Para tanto, empregou-se a teoria da estratégia como prática social e o método de pesquisa descritiva de natureza interpretativa. As análises dos resultados da pesquisa revelam que a organização estudada tem procurado construir estratégias ambientais marcadas pelas práticas de eco-eficiência, mitigação de impactos sócioambientais e construção de imaginário relativo à responsabilidade sócio-ambiental.
\end{abstract}

Palavras-chave: Participação, organização, celulose.

\section{INTRODUCTION}

Researchers in various academic fields have joined the discussions about the impact of forestry and industrial activities on cellulose production. Many cellulose pulp production methods are incompatible with the forestry activities currently employed by organizations in this industry. Thus, a number of researchers from different universities have begun to discuss and explore the resulting socio-environmental problems.

These discussions have gained attention, acquired social and academic legitimacy, and have encouraged the organizations in this sector to reflect on their socioenvironmental policies as response mechanisms to the challenges that different elements of the market and society impose. Some of these challenges include pressures from legislators, shareholders, investors, financiers, consumers and environmentalists; these actors now require organizations in forestry and cellulose production to adopt new strategies and methods of dealing with the environment.

The aim of this article was to study the environmental strategies of a forest-based, cellulose pulpproducing organization using theoretical frameworks such as social practice. Our choice of this approach was influenced by the predominance of normative-prescriptive approaches that originated in the classical school of strategic management and that answer the need for new explanations for collective activities in organizations (Jarzabkowski, 2004, 2005; Jarzabkowsky \& Seidl, 2008; Mantere \& Vaara, 2008; Whittington, 2004, 2006).

These authors argued that this perspective reformulated the epistemological and ontological assumptions of classical strategic approaches and thus dismantled some of the traditional dualities (formulation/ implementation; content/process; conception/execution).

\footnotetext{
${ }^{1}$ Administrator, Professor MS in Administration - Escola Superior Aberta do Brasil (ESAB) - Avenida Santa Leopoldina, 840 - $29102-$ 040 - Vila Velha, ES - admbeatriz@gmail.com

${ }^{2}$ Administrator, Professor DS in Administration - Departamento de Administração e Economia/DAE - Universidade Federal de Lavras/ UFLA - Cx. P. 3037 - 37200-000 - Lavras, MG - mozarjdb@dae.ufla.br

${ }^{3}$ Agronomy engineering, Professor, DS in Administration candidate, sponsored researcher at PMCD/FAPEMIG - CAPES (Minas Gerais Teacher-Training Program/ Research Support Foundation of the State of Minas Gerais - Coordination of Personnel in Higher Education) Departamento de Administração e Economia/DAE - Universidade Federal de Lavras/UFLA - Cx. P. 3037 - 37200-000 - Lavras, MG vgpbrito@dae.ufla.br
}

Cerne, Lavras, v. 16, n. 3, p. 367-372, jul./set. 2010 
They also proposed that complex thinking can be embodied in their theories about the implementation of a strategy (Balogun \& Johnson, 2004, 2005; Jarzabkowski et al. 2007; Laine \& Vaara, 2007; Regnér, 2008; Seidl, 2007).

Jarzabkowski et al. (2007) have advocated a strategic approach as a social practice that considers the praxis, the practice and the practitioners. For the authors, strategy as social practice should be a set of activities that are undertaken based on interaction, negotiation and action, and that the individuals in a given socio-historical context articulate. This concept closely resembles Schatzki's argument (2005) that practice concerns what people say and do based on an organizational logic or praxis and on their actions in a determined social space. They represent a combined set of actions that their practitioners organize according to a social order that they agree upon amongst themselves.

The praxis combines theory and practice into the same "nexus", which signals or characterizes human activity in a given organization. The praxis of an organization would be a nexus that reconciles the actions undertaken in the organization in a given context with the justifications for these same actions. In other words, praxis refers to the process by which a theory is put into practice and the way it is made a part of living experience or social reality. It could be argued that praxis is embodied in organizational life, because strategy theorists regard it as conscious action, characterizing the social activities that produce the strategic effects that social groups and organizations need to survive.

These practices are everyday activities that are relatively stable and composed of various features. They concern organizational entities that act as intermediaries between structures and actions or everyday events; they may include spatial-temporal signals, discourses, different kinds of awareness, conflicts, symbolic production, actions, types of knowledge, tools, methods of work and objects. For theorists, practice is intrinsically linked to organizational reality because it supplies the physical, rational, instrumental, cognitive and behavioral resources required for the collective development of an organization's reality (Jarzabkowski et al., 2007; Jarzabkowski \& Seidl, 2008; Laine \& Vaara, 2007; Regnér, 2008; Seidl. 2007). These authors have argued that practice should be the basic analytical unit for studying strategy. In their definition, a wide range of actors define a strategy, acting in a given organizational context that is characterized by a praxis shared by the strategy's practitioners. The strategy approach (when conceived as practice) assumes that these practitioners are people who take an active part in developing the praxis and everyday activities that effectively support the growth and survival of the organization's competitive environment (Chia \& Mackay, 2007).

These people should be seen as subjects involved in the process of developing an organizational reality. Thus, they possess the consciousness and autonomy to think, act and develop the organizational practices that can benefit their organization (Jarzabkowski \& Sillince, 2007). These authors postulated that researchers could investigate strategy as social practice by examining the relationships between the praxis, practices and practitioners because the implementation of a strategy should be regarded as the nexus between these three analytical categories. Conceptually, this study assumes that there is a link between the praxis and the practices followed by the actors who develop strategies for an organization's everyday life.

According to Jarzabkowski et al. (2007) and Jarzabkowski \& Seidl (2008), the strategic approach as practice recognizes the value of the strategist's world-view (experiences, knowledge and identity) and defines strategy as a phenomenon that is situated in a given social-historical context; that incorporates a flow of activities carried out collectively; and that has important implications for a group, organization or sector. These authors stress that this approach aims to create knowledge that can identify the strategists, their conceptions, their actions, the development of their practices, and the extent of their impact on the micro and macro social activities that are organized and implemented collectively (Jarabkowski et al, 2007; Jarabkowski \& Wilson, 2006).

\section{METHODOLOGY}

In this study, we used interpretive and descriptive research methods (Severino, 2000). We assumed that both the studied organization and its socio-environmental strategies are realities that its members developed socially. These actors combine praxis as premise for action and everyday practices as representations of what has actually been done.

The complex nature of the studied phenomenon required us to combine different methods of data collection, including documentary analysis, interviews and nonparticipative observation. Specifically, we undertook documentary analysis by examining local and state

Cerne, Lavras, v. 16, n. 3, p. 367-372, jul./set. 2010 
newspapers and by analyzing the information available on the corporate information, internal communication, and official documents that define management policies and statutes. Our study of these resources allowed us to gather information on the organization's background and macro social context.

We conducted interviews with four managers, two specialists and four employees. Their everyday practices are closely linked when they implement strategies at the forest-based cellulose producer, which we will refer to as CELETEC. The non-participative observation was conducted during four visits to the organization's industrial plant. Our application of these research techniques not only allowed us to contextualize the problem under study, but also provided a benchmark for a broader and more in-depth view of the reality we studied. After the first stage, during the first semester of 2004, we started systematizing the data and analyzing the content of the interviews (Bardin, 1994). Our analysis began with a preliminary analysis, which included the organizational stage and the systematization of the interview and documentary data. This analysis was performed according to the criteria of exhaustiveness, representativeness, uniformity and relevance. The next stage was an investigation of the gathered data, including codifying, thematic crosscutting and sorting. The final stage was analysis and interpretation of the results.

\section{RESULTS AND DISCUSSION}

Understanding the socio-environmental strategies of CELETEC requires a description of its developmental period and entrance into the national and international market and an analysis of the socio-environmental strategies that its practitioners have jointly developed. In this section, we present this information, which is the result of our interpretative descriptive study.

\subsection{The socio-historical background of CELETEC}

CELETEC was established in the 1970s, and has risen to prominence as one of the main global producers of cellulose pulp. It bases its management model and cellulose pulp production on the principles of sustainable development. This organization was founded in a period when Brazil's industrial development was driven by policies that replaced imports with local products. These policies encouraged the diversification of regional and local economies by offering financial incentives and subsidized interest rates for the creation of industrial plants in regions regarded, at that time, as requiring special economic treatment.

In this socio-economic context, CELETEC initiated strategies that would ensure its industrial growth and international position. It became a leading producer of bleached eucalyptus pulp, accounting for about $24 \%$ of the world's supply, and played a prominent international role as a result of its corporate sustainability policies. Its forestry operations occupy an inter-state area of almost 300,000 hectares, consisting of renewable eucalyptus plantations sustained by about 170,000 hectares of native forest reserves. This enterprise has an annual nominal capacity of approximately 3.2 million tons of bleached pulp and exports to countries all over the world. The organization was founded at a time when the protection of the environment was not an important issue in the business world. Moreover, social and environmental movements were politically controlled, which made it difficult to initiate debate about the environmental impact of the industry and forestry businesses in different regions of Brazil.

Starting in the mid-1980s, this situation changed dramatically due to the process of redemocratization in Brazil. Environmental movements were able to consolidate and started to question the socio-economic approach that companies that in different sectors of the economy adopted, particularly those that were (and still are) producing cellulose pulp. However, the emergence of the environmentalist movement alone does not explain the way CELETEC changed its strategy over time.

Other factors also prompted CELETEC to create socio-environmental strategies to alleviate the impact of the company's forestry and industrial activities. These factors included the required environmental certification for international buyers of cellulose pulp, the increasing environmental awareness among certain social groups, the development of scientific and technological knowledge that led to changes in systems of forest handling, and the implementation of cleaner technology for cellulose pulp production. We attempted to understand these strategies by explaining the strategic concepts and by highlighting the relationship between praxis and the socio-environmental practices that organization members adopted. In particular, we tried to understand the formation of socio-environmental strategies, their reasons, and their micro and macro social repercussions (Jarzabkowski, 2007).

Cerne, Lavras, v. 16, n. 3, p. 367-372, jul./set. 2010 
3.2 Strategy as social practice: the objective of socioenvironmental praxis

Based on our analysis of the documents and interviews, it was clear that the organizational praxis that the practitioners of socio-environmental strategies developed was characterized by different assumptions that originated in the organization's history. The key assumptions that stood out were: the strategic guidelines for the future and the international market; the search for a balance between global involvement and local actions for sustainability; recognition of the value of scientific and technological knowledge as a mechanism to overcome socio-environmental problems; recognition of socioenvironmental conflicts as potential mechanisms to improve industry's treatment of the environment; pragmatism as a means for eco-efficiency; recognition of the value of environmental education as a tool for manipulating corporate image; entrepreneurial vocation and guidance for socio-environmental goals as a way to maintain a company's economic, social and environmental sustainability.

Our analysis of the results of this interpretive, descriptive study showed that developing a strategic praxis (as a premise for action) is not a linear process. On the contrary, this process must be seen as a socio-historical product that created a kind of organizational "isomorphism", which strengthened organizational legitimacy and growth.

In sum, CELETEC formulated and implemented a set of socio-environmental practices to act as mechanisms in establishing the logic of action or organizational praxis. These socio-environmental practices include the fullyintegrated handling of eucalyptus plantations and the preservation of the eco-systems; the expenditure of financial resources on research and the development of new species; the implementation of programs on ecoefficiency; ISO 14001 Certification; environmental education; the recovery of hydrographic basins; the adoption of public relations marketing strategies; and the development of a social approach that preserves the company's corporate image.

An analysis of this study's results also shows that these socio-environmental practices were institutionalized as the organization gained an international presence; it learned how to develop new scientific knowledge and incorporate it into everyday practices. ISO 14001 Certification, which was granted to CELETEC in 1999, can be regarded as the result of the collective efforts of managers, researchers, consultants and employees. The active involvement of these organizational actors, who introduced new production technology (industrial and forestry) and socio-environmental education, encouraged the development of a shared logic of action in the organization.

This certification is not just an award or a formalization of policies and organizational structure to symbolize an organization's proactive efforts. Rather, it embodies a set of everyday practices that reduce environmental damage and preserve natural resources.

Since its founding, CELETEC has invested in new knowledge on forest handling, the genetic improvement of plants, the development of new products and cleaner processes of cellulose production, recovery techniques of industrial waste, biological control of the eucalyptus weevil, water and soil conservation techniques and measures to prevent the outbreak of forest fires. Moreover, in 1973, it created the Center for Research, Development and Innovation, which works to develop and share expertise with managers, specialists and the workforce through professional training and socio-environmental education. This collective expertise, which helps CELETEC to maintain a competitive edge and play a market-oriented role, has improved the organization's relationship to the environment and acts as a benchmark for other organizations.

To maintain this organizational excellence, strategists (managers, researchers, consultants and workers) must implement the principles of eco-efficiency and seek environmental excellence. Our analysis of the everyday activities that the practitioners of socioenvironmental strategies developed allows us to conclude that there is a parallel between theory and practice. In other words, in the studied organization, we observed that the company's philosophy of environmental management was in harmony with its strategies.

We also observed that socio-environmental strategies are the result of a collective vision that has been designed or achieved through the everyday practices that make CELETEC the standard for socio-environmental management. These practices include the integrated handling of projects to combine various socioenvironmental aspects, such as climate, soil, water resources, and bio-diversity, and the project's relationship to local communities. These measures have yielded results that CELETEC regards as important for the maintenance, or even improvement, of the ecosystem of soil, water, and

Cerne, Lavras, v. 16, n. 3, p. 367-372, jul./set. 2010 
plants and for the preservation of biodiversity and water resources in CELETEC's local area.

The company's strategists have also implemented marketing practices to strengthen the company's corporate image. These practices include the voluntary involvement of the employees in social projects; the forming of partnerships with farmers for the development of forestry projects; financial investment in environmental education programs aimed at training employees and members of the community; and the sponsorship of events related to the preservation of cultures in the organization's region.

In addition to making these social investments, some of the organization's strategists have attended various meetings and discussion-groups to discuss the organization's relationship with the environment. They have also adopted an open-door transparency policy to strengthen the ideology and practices of sustainability, discussed above. Moreover, they have taken an active part in events and seminars to spread the message that "the eucalyptus tree is economically, environmentally and socially sustainable". A number of publications have reported positively on CELETEC's socio-environmental practices.

CELETEC's practitioners have also jointly undertaken the socio-environmental practice of forming close ties with the local community and non-governmental organizations. This process opened up channels of communication, particularly with the small rural landowners and the inhabitants of regions on the borders of CELETEC's eucalyptus plantations and native reserves. Under this program, the producers visit the industrial plants, and/or the strategists visit the communities. These visits led to an exchange of experiences between the specialists and the producers and enabled them to communicate. In recent years, groups of students, members of community associations, representatives of NGOs and the communities, customers, journalists, and others have visited the industrial plant. The strategy practitioners have published and disseminated socio-environmental reports that publicize their actions and lay out their goals for the following year.

\section{CONCLUSIONS}

The aim of this research was to study the socioenvironmental strategies of a forest-based, cellulose pulpproducing organization by employing strategic theory as social practice and interpretative, descriptive research methods. Our discussions and analyses of the results show that CELETEC's socio-environmental praxis is based on principles that combine theory and practice. It is used as a guiding mechanism for collective action and communication channel between CELETEC, the environment and society.

It was evident that CELETEC developed its organizational praxis based on the collective knowledge that emerged from the practices adopted to troubleshoot external adaptation and from the internal integration necessary for CELETEC's environmental policy. The organization faced the challenges of attaining pre-set objectives, overcoming socio-environmental problems and achieving a degree of consensus between the different interest groups surrounding it.

This praxis embodies a worldview that involves the use and preservation of natural resources and the mobilization of symbolic or imaginary systems. This praxis generates a form of structural coherence necessary for the organization's sustainability and includes both mediation of socio-environmental conflicts and the development of strategies that minimize its environmental impact.

In summary, the organization attempts to engage in discourses and management practices that can ensure its productivity and efficiency with minimum environmental impact. It has worked to establish its image as an open and transparent organization in the sphere of socio-corporate responsibility. However, despite its collective efforts to adopt socio-environmental strategies, CELETEC has been sharply criticized by the press, environmental movements, non-governmental organizations and public defenders, especially for the socio-environmental impact of the eucalyptus monoculture. It should be stressed that this study is not concerned with these conflicts. However, we suggest that this phenomenon will be the subject of future analytical research about socio-environmental strategies in other forest-based organizations.

On one hand, our descriptive study suggests that CELETEC's different strategic practices may become benchmarks to be replicated by other forest-based enterprises. On the other hand, our study also provides evidence that this replication cannot simply apply the same socio-environmental strategic practices. Regardless of the nature of an organization, strategic practice will always be a product of an active socio-historical movement that is organizationally re-structured on a daily basis. Each organization has its own identity and must develop its own individual socio-environmental strategies.

Thus, each organization must follow its own path and incorporate new kinds of knowledge and forms of technology to protect the environment, new management attitudes and new everyday actions. Organizations must

Cerne, Lavras, v. 16, n. 3, p. 367-372, jul./set. 2010 
adopt a more pro-active stance with regard to environmental preservation. Finally, it should be recognized that multiple factors (i.e., economic, political, social, legal, cultural and environmental) affect the application of socio-environmental strategies.

In light of this, the generalization of one organization's socio-environmental strategies to other contexts requires significant thought and enthusiasm on the part of practitioners. Strategic theory as social practice aims to present explanations that reduce the risks of generalizing and standardizing best practices, which other organizations cannot always reproduce in the same form. Nonetheless, despite the risks of generalizing socioenvironmental strategies, CELETEC's experience, as outlined in this article, can serve as a benchmark for other forest-based organizations that seek to address the environmental impact of agro-forestry activities.

Despite these limitations, we believe that this research can contribute to the growing importance, in the Brazilian context, of research methods that investigate strategy as social practice. This approach is not limited to the definition of objectives and purposes; ultimately, its implementation is a task for the executive group that envisions and defines an organization's working philosophy. Furthermore, this study has sought to identify the practitioner-strategists, their conceptions, actions, the development of their practices, and the micro and macro social implications of their collective activities.

\section{BIBLIOGRAPHICAL REFERENCES}

BALOGUN, J.; JOHNSON, G. From intended strategies to unintended outcomes: the role of change recipient sense making. Organization Studies, v. 26, n. 11, p. 1573-1601, Nov. 2005.

BALOGUN, J.; JOHNSON, G. Organizational restructuring and middle manager sense making. Academy of Management Journal, v. 47, n. 4, p. 523-549, Oct. 2004.

BARDIN, L. Análise de conteúdo. Lisboa: Edições 70, 1994. 229 p.

CHIA, R.; MACKAY, B. Post-processual challenges for the emerging strategy-as-practice perspective: discovering strategy in the logic of practice. Human Relation, London, v. 60, n. 1, p. 217-242, Jan. 2007.

JARZABKOWSKI, P. Strategy as practice: an activity-based approach. London: Sage, 2005. 260 p.

Cerne, Lavras, v. 16, n. 3, p. 367-372, jul./set. 2010
JARZABKOWSKI, P. Strategy as practice: recursiveness, adaptation and practices-in-use. Organization Studies, London, v. 25, n. 4,p. 529-560, May 2004.

JARZABKOWSKI, P.; BALOGUN, J.; SEIDL, D. Strategizing: the challenges of a practice perspective. Human Relations, London, v. 60, n. 1, p. 5-27, Jan. 2007.

JARZABKOWSKI, P.; SEIDL, D. The role of meetings in the social practice of strategy. Organization Studies, London, v. 29, n. 11, p. 1391-1426, Nov. 2008.

JARZABKOWSKI, P.; SILLINCE, J. A rhetoric-in-context approach to building commitment to multiple strategic goals. Organization Studies, London, v. 28, n. 11, p. 1639-1665, Aug. 2007.

JARZABKOWSKI, P.; WILSON, D. C. Actionable strategy knowledge: a practice perspective. European Management Journal, v. 24, n. 5, p. 248-367, Oct, 2006.

LAINE, P. M.; VAARA, E. Struggling over subjectivity: a discursive analysis of strategic development in an engineering group. Human Relations, London, v. 60, n. 1, p. 29-58, 2007.

MANTERE, S.; VAARA, E. On the problem of participation in strategy: a critical discursive perspective. Organization Science, Pittsburgh, v. 19, n. 2, p. 341-358, Apr. 2008.

REGNÉR, P. Strategy-as-practice and dynamic capabilities: steps towards a dynamic view of strategy. Human Relation, London, v. 61, n. 4, p. 565-588, Apr. 2008.

SCHATZKI, T. R. The sites of organizations. Organizations Studies, London, v. 26, n. 3, p. 465-484, May 2005.

SEIDL, D. General strategy concepts and the ecology of strategy discourses: a systemic-discursive perspective. Organization Studies, London, v. 28, n. 2, p. 197-218, Feb. 2007.

SEVERINO, A. J. Metodologia do trabalho científico. São Paulo: Cortez, 2000.

WHITTINGTON, R. Completing the practice turn in strategy research. Organization Studies, London, v. 27, n. 5, p. 613634, Dec. 2006.

WHITTINGTON, R. Strategy after modernism: recovering practice. European Management Review, Belgium, v. 1, n. 1, p. 62-68, Jan. 2004. 